\title{
The Unemployment Gender Gap during the 2007 Recession
}

\author{
Ayşegül Şahin, Joseph Song, and Bart Hobijn
}

\begin{abstract}
Women fared decidedly better than men during the most recent recession. By August 2009, the unemployment rate for men had hit 11.0 percent, while that for women held at 8.3 percent. This 2.7 percentage point unemployment gender gap - the largest in the postwar era-appears to reflect two factors: First, men were much more heavily represented in the industries that suffered the most during the downturn. Second, there was a much sharper increase in the percentage of men who-prompted, perhaps, by a decline in household liquidity — rejoined the labor force but failed to find a job.
\end{abstract}

C onditions in the nation's labor market have deteriorated dramatically during the most recent recession. The unemployment rate- 5.0 percent at the start of the recession in December 2007 — rose to a peak of 10.1 percent in October 2009, its highest level since the 1981-82 recession. During the same period, nonfarm payroll employment shrank 6.1 percent, entailing a loss of 8.4 million jobs. The payroll employment figures, still bleak at the start of 2010, recall the payroll declines of 1946, when in a span of nine months employment fell 6.9 percent, resulting in 2.9 million job losses.

A breakdown of the employment figures shows that men have been affected more adversely than women during the 2007 downturn. Between December 2007 and October 2009 , nonfarm payroll employment fell 5.8 million for men but dropped only 2.5 million for women. While male and female unemployment rates were roughly equal at the start of this period - 5.1 percent and 4.9 percent, respectively — they have since diverged markedly. In August 2009, the unemployment rate for men stood at 11.0 percent while that for women was 8.3 percent $-\mathrm{a} 2.7$ percentage point difference that constitutes the largest unemployment gender gap in the postwar era. ${ }^{2}$ Although the gap has closed in recent months, it still persists at a very high level in relation to historical standards.

In this edition of Current Issues, we attempt to explain the dramatic disparity between men's and women's unemployment rates in the 2007 recession by analyzing gross labor flows data from the Bureau of Labor Statistics (BLS). The data measure the movement of people between employment, unemployment, and a third state that the BLS terms "not in the labor force" and that we render as "nonparticipation" in this article. ${ }^{3}$ We use the data to calculate unemployment inflow and outflow rates for men and women separately-statistics that in turn help us identify gender differences in labor supply responses (movements between labor force participation and nonparticipation) and job-loss and job-finding prospects (movements between unemployment and employment). Our breakdown of the gross labor flows data reveals that the large

\footnotetext{
${ }^{1}$ We refer to the most recent recession by its start date (the "2007 recession") at many points in this article.

${ }^{2}$ We define the unemployment gender gap as the difference between the male and female unemployment rates.

${ }^{3}$ The three labor force states are defined in the section on gross labor flows data.
} 
Chart 1

\section{Payroll Employment}

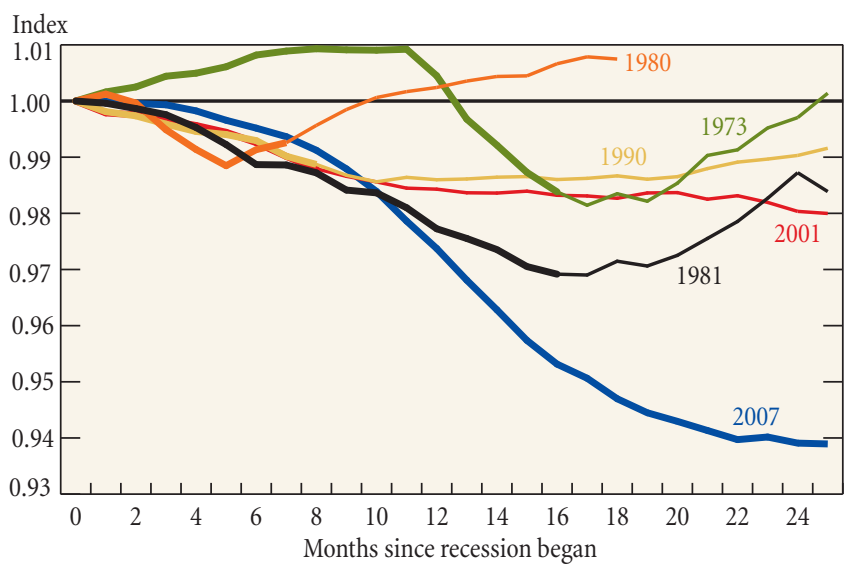

Source: U.S. Department of Labor, Bureau of Labor Statistics.

Notes: The chart shows the payroll employment series normalized to one at the start of each recession. The thicker portion of each line depicts the months in recession. We end the 1980 line at the eighteenth month because the 1981 recession began nineteen months after the start of the 1980 recession.

gender gap is primarily attributable to an unemployment inflow rate that increased nearly twice as much for men as it did for women during the 2007 recession. This disproportionate increase for men in turn reflects two factors: the high concentration of men in the sectors that were hit hardest by the recession, and an increase in the percentage of men who entered (or reentered) the labor market after a period of nonparticipation - prompted, perhaps, by a decline in their household wealth and savings — and then failed to find a job.

\section{The Labor Market during the 2007 Recession}

Payroll employment began to decline in December 2007, the month identified by the National Bureau of Economic Research (NBER) as the start of the recession. Between December 2007 and August 2008, payroll employment dropped by slightly more than 1.2 million jobs, or 134,000 jobs per month on average. After the deepening of the financial crisis during the summer of 2008, the pace of job declines quickened. Between August 2008 and January 2010, the U.S. labor market shed close to 7.2 million jobs, a contraction amounting to 424,000 jobs per month. The total job losses brought payroll employment back to its September 1999 level, erasing all of the jobs created over the past decade.

Compared with job declines in the last five recessions, the most recent decline in employment stands out as the longest and most severe. This distinction is evident in Chart 1 , which presents the payroll employment series normalized to one at the start of each recession in the past four decades. ${ }^{4}$ In the most recent recession, payroll employment fell 6.1 percent from its December 2007 level. Employment

\footnotetext{
${ }^{4}$ For consistency, we analyze the employment data according to the NBER business cycle dates rather than the peak to trough of the employment data.
}

\section{Chart 2 \\ Nonfarm Payroll Employment By Gender}

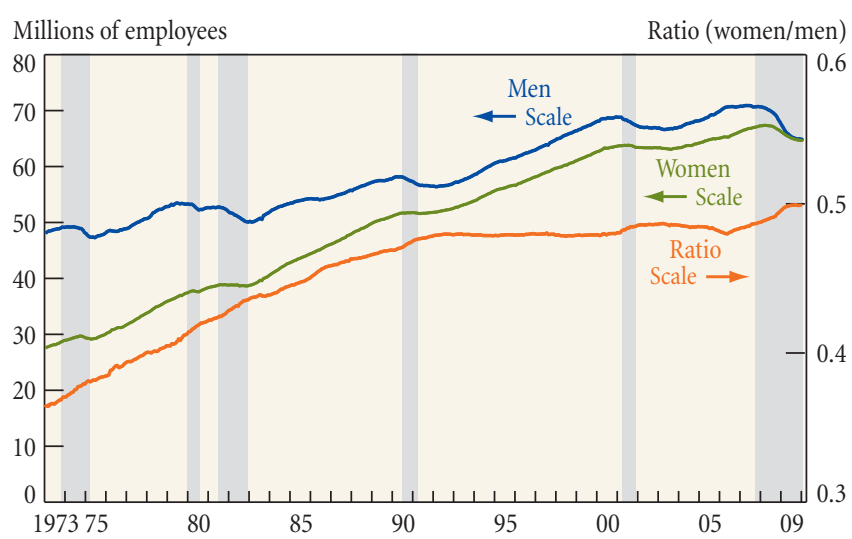

Source: U.S. Department of Labor, Bureau of Labor Statistics.

Note: The shaded areas indicate periods designated recessions by the National Bureau of Economic Research.

dropped for twenty-two consecutive months; subsequently, a net gain of 64,000 jobs was posted in November 2009, but this modest increase was quickly erased in the following month. The only other employment decline that approaches the most recent one in severity and length occurred during the 1981-82 recession, when payrolls dropped 3.1 percent over a period of sixteen months.

In conjunction with the employment decline, the overall unemployment rate more than doubled, rising from 5.0 percent at the start of the recession to a peak of 10.1 percent in October 2009. The unemployment rate had not been this high since the 1981-82 recession, when it reached 10.8 percent.

While the aggregate data on job losses and unemployment reveal much about the severity of the employment downturn, they conceal substantial differences in the way men and women have fared during the most recent recession. A breakdown of the nonfarm payroll employment data by gender shows a much bigger drop for men than women (Chart 2). From the start of the recession in December 2007 to January 2010, payroll employment declined 8.2 percent for men but only 3.9 percent for women. Although the declines for both men and women are the highest in the past four decades, men have been disproportionately affected. As a consequence, for the first time on record, the number of women on U.S. payrolls closely rivals the number of men.

Men have also experienced a significantly higher rate of unemployment than women during the most recent recession. The difference in rates peaked in August 2009, when men's unemployment reached 11.0 percent while women's was 8.3 percent (Chart 3 ). Prior to the 1980 recession, the unemployment rate for women exceeded that for men by a fairly large margin. During the 1980 recession, however, the male unemployment rate jumped to 7.8 percent, not 
Chart 3

\section{Unemployment Rates}

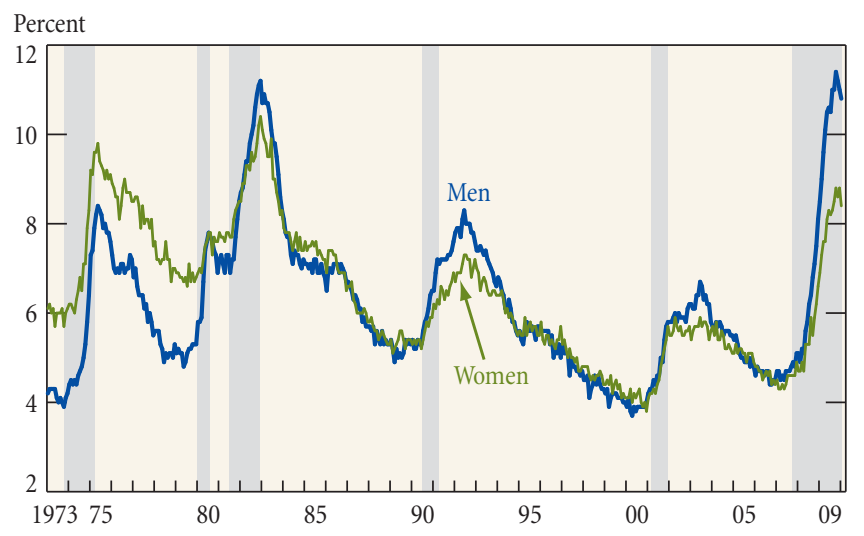

Source: U.S. Department of Labor, Bureau of Labor Statistics.

Note: The shaded areas indicate periods designated recessions by the National Bureau of Economic Research.

only closing but even reversing the unemployment gender gap. Since then, the unemployment rate for men has persisted at higher levels than that for women during and shortly after recessions, while during expansions, gender-specific unemployment rates have tended to converge. The 2007 recession follows this same sequence: The large gender gap observed in August 2009 emerged over the course of the recession, but at the start of the downturn, the unemployment rates for men and women were very similar. However, while the 2007 recession conforms to the same basic pattern as its predecessors, the disparity in unemployment rates in this most recent downturn is much more marked than in earlier cycles. The 2.7 percentage point gender gap observed in the 2007 recession far exceeds the 1.0 percentage point average gap that prevailed in the past three recessions.

One indicator that has proved to be similar for men and women during the 2007 recession is the average duration of unemployment. Since the start of the recession, the average time that the unemployed have spent looking for jobs has shot up (Chart 4). The rise in this measure has followed a parallel course for men and women. In December 2007, the average duration of unemployment stood at 16.0 weeks for men and 16.9 weeks for women; by August 2009 , the peak of the gender gap, it had risen to 25.0 weeks for both groups. In recent months, the measure has climbed higher for men than for women-31.2 weeks compared with 28.8 weeks in January 2010 — but the difference is still modest.

To clarify the dynamics underlying the recent labor market outcomes for men and women, we next present evidence on gross labor flows.

\section{Gross Labor Flows Data}

In October 2007, the Bureau of Labor Statistics began to release seasonally adjusted monthly estimates of labor force flows going
Chart 4

\section{Average Duration of Unemployment}

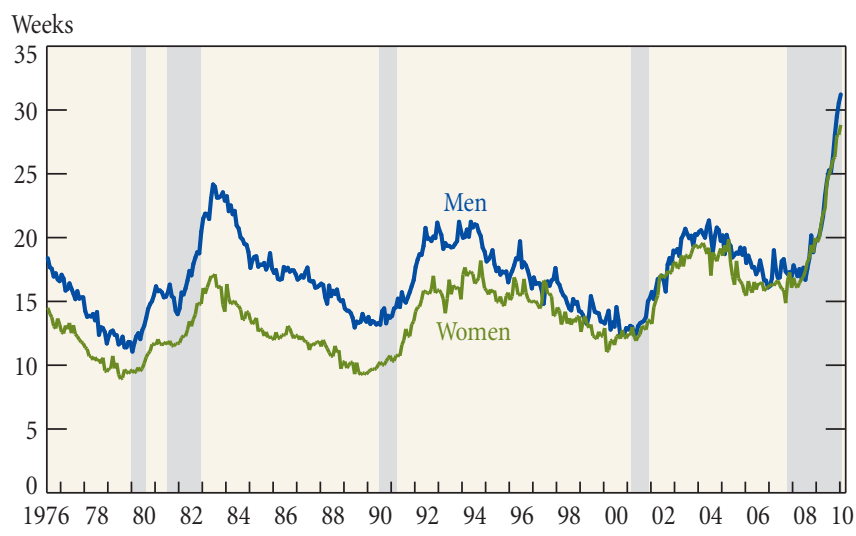

Source: U.S. Department of Labor, Bureau of Labor Statistics.

Note: The shaded areas indicate periods designated recessions by the National Bureau of Economic Research.

back to $1990 .^{5}$ The data series reports month-to-month flows between three distinct labor market states: employment, unemployment, and nonparticipation. The first state applies to those who have jobs and the second state to those who are jobless but actively looking for work. The third state applies to those who are jobless and not looking for paid work - for example, retirees, students of working age, and homemakers. ${ }^{6}$ The data series tracks individuals movements between the three states.

The flows data have clear advantages over the "stock" data on individuals' work status. The stock data convey only the net change in the number of people employed, unemployed, or not in the labor force over a certain period. The flows data, however, provide information on the source of the net change. For example, the flows data reveal whether a worker who has left unemployment has done so by finding a job or by withdrawing from the labor force. While both moves would decrease the stock of unemployed workers by one, they would be represented in the flows data as two very distinct transitions: one a job-finding transition (unemployment to employment) and the other a labor-supply response (unemployment to nonparticipation in the labor force).

If the flows data are decomposed by gender, it is possible to compare men's and women's movements in the labor market. These findings in turn can provide insight into the reasons for the asymmetrical labor outcomes of men and women during the most recent recession. A detailed description of the calculation of the flows data can be found in the box on page 4 .

\footnotetext{
${ }^{5}$ Since the data only go back to 1990 , we limit our analysis to the unemployment inflows and outflows for the 1990-91,2001, and 2007 recessions.

${ }^{6}$ A more in-depth explanation of the three labor market states can be found at http://www.bls.gov/cps/cps_htgm.htm.
} 


\section{How the Flows Data Are Calculated}

Each month, as part of its Current Population Survey, the BLS collects information on the labor force activities of roughly 110,000 individuals. Using this information, the BLS identifies each individual as belonging to one of the three labor force states: employed (E), unemployed (U), or not in the labor force $(\mathrm{N})$. In subsequent months, the Bureau conducts follow-up interviews to establish whether the individual has remained in the same state or moved to one of the other two states.

In the diagram below, the circles denote the stock of people who are employed, unemployed, or not in the labor force, while the arrows represent the flows of individuals between states. In the notation of the flows, the first letter denotes the individual's labor force status in month $t$ and the second letter, his or her status in the month $t+1$. For example, "UE" would describe an individual who is unemployed during January but then obtains some form of employment in February.

\section{Labor Force Flows}

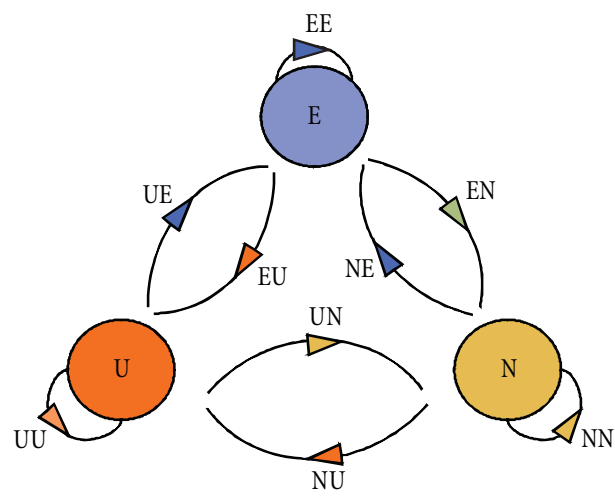

E: Employment

$\mathrm{U}$ : Unemployment

$\mathrm{N}$ : Nonparticipation in the labor force

Using the BLS data, we calculate the flow rate for each of the movements pictured above. The flow rate is the fraction of people who are in a particular state in one month and move to another state the next month. (For example, the UE flow rate is the fraction of unemployed workers in one month who have a job the next month.) We then compute the flow rates by gender.

\section{Decomposition of the Labor Market Flows Data}

In examining the flows data, we focus on the flows in and out of unemployment. ${ }^{7}$ Unemployment inflows consist of people, initially either employed or not in the labor force, who then move into unemployment; unemployment outflows consist of people who are initially unemployed but then obtain employment or

\footnotetext{
${ }^{7}$ Before the flows data became publicly available, researchers estimated the unemployment flow rates using unemployment stock data (Shimer 2005; Hall 2006; Elsby, Hobijn, and Şahin 2009). However, these estimations did not consider the flows between unemployment and nonparticipation.
}

leave the labor force. ${ }^{8}$ We use data on these flows during the last three recessions to calculate the rates at which the population moves in and out of unemployment.

We find that during all three recessions, the unemployment inflow rates for both men and women increased while the outflow rates decreased (Charts 5 and 6). In the 1990-91 and 2001 recessions, the flows in both directions were roughly comparable for men and women. As the two groups faced the layoffs that generally occur during downturns, they experienced increases in their inflow rates into unemployment that were within about six percentage points of each other in 1990-91 and about two percentage points of each other in 2001(Table 1). And with the chances of finding a job significantly diminished, men and women experienced percentage declines in their outflow rates from unemployment that were within about five percentage points of each other in 1990-91 and about four percentage points in 2001.

In the most recent recession (December 2007 to the peak of the gender gap in August 2009), the decline in outflow rates from unemployment has again been similar for men and women: 27.8 percent and 23.3 percent, respectively. The similarity implies that men and women were equally likely to leave unemployment - a finding that helps explain why the average duration of unemployment in the 2007 recession was so much alike for men and women. However, the male inflow rate into unemployment has increased dramatically more than the female inflow rate-by 62.6 percent as against 35.6 percent. Together, these conditions explain the much larger increase in the male unemployment rate and the dramatic widening of the unemployment gender gap.

Since the peak of the gender gap, the unemployment inflow rates for men and women have declined (Table 1, row 4). However, the rates for both groups remain above their historical averages.

\section{Decomposition of the Inflow and Outflow Rates}

Because the unemployment inflow and outflow rates mask the specific source of the movements in and out of unemployment, we decompose the flow rates further to get a better understanding of the dynamics of the unemployment rate gender gap. As noted earlier, the inflow and outflow rates each consist of two distinct flows. The unemployment inflow rate encompasses people who move from employment to unemployment (designated in this article by the abbreviation $\mathrm{EU}$ ) and people who move from nonparticipation in the labor force to unemployment (NU). The outflow rate is composed of people who move from unemployment to employment (UE) and from unemployment to nonparticipation (UN).

The left panel of Chart 7 shows, separately for men and women, the inflow rates to unemployment from employment

\footnotetext{
${ }^{8}$ Some examples may be helpful: The retired worker or student who is prompted by financial pressures to enter the labor force and search actively for a job typifies the transition from nonparticipation to unemployment. The reverse flow, from unemployment to nonparticipation, might be represented by the person who has been actively looking for work but because of discouragement or illness discontinues the search.
} 


\section{Decomposition of Unemployment Rate Moves}

\begin{tabular}{|c|c|c|c|c|c|c|}
\hline \multirow[b]{2}{*}{ Recession } & \multicolumn{2}{|c|}{ Inflow Rate (Percentage Change) } & \multicolumn{2}{|c|}{ Outflow Rate (Percentage Change) } & \multicolumn{2}{|c|}{ Change in Unemployment Rate } \\
\hline & Men & Women & Men & Women & Men & Women \\
\hline July 1990-March 1991 & 18.9 & 12.7 & -10.7 & -5.4 & 1.6 & 0.9 \\
\hline March 2001-November 2001 & 14.5 & 16.3 & -11.2 & -7.1 & 1.4 & 1.2 \\
\hline December 2007-August 2009 & 62.6 & 35.6 & -27.8 & -23.3 & 5.9 & 3.4 \\
\hline December 2007-January 2010 & 52.8 & 31.5 & -28.5 & -26.4 & 5.7 & 3.5 \\
\hline
\end{tabular}

Sources: U.S. Department of Labor, Bureau of Labor Statistics; authors' calculations.

Chart 5

Unemployment Inflow Rates

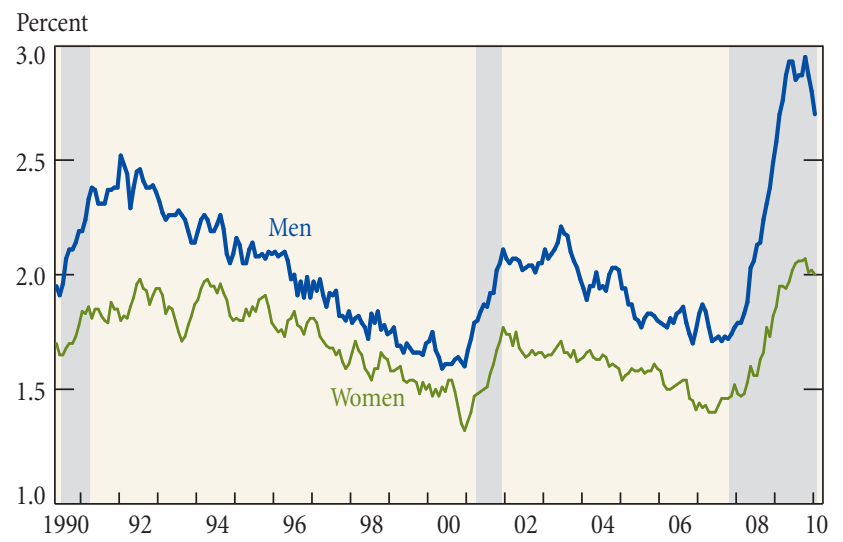

Source: U.S. Department of Labor, Bureau of Labor Statistics.

Note: The shaded areas indicate periods designated recessions by the National Bureau of Economic Research.
Chart 6

\section{Unemployment Outflow Rates}

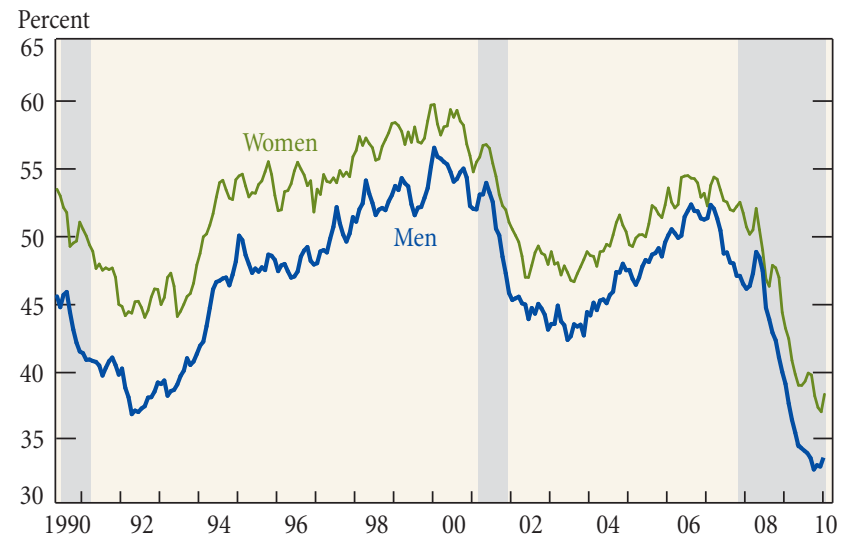

Source: U.S. Department of Labor, Bureau of Labor Statistics.

Note: The shaded areas indicate periods designated recessions by the National Bureau of Economic Research. and nonparticipation during the most recent recession. A stark difference is evident in the employment to unemployment transition rates of men and women. From the start of the recession to the peak of the gender gap in August 2009, the EU flow rate for men increased from 1.4 percent to 2.2 percent, while over the same period the corresponding rate for women rose only from 1.1 percent to 1.5 percent. Moreover, even though both men and women experienced an increase in NU flow rates (entering the labor force but not finding employment), the increase for men was decidedly greater, rising from 2.8 percent to 4.5 percent as compared with an increase from 2.1 percent to 2.9 percent for women.

By contrast, the outflow rates from unemployment during the most recent recession behaved similarly for men and women (Chart 7, right panel). The UE flow rate for men fell from 28.6 percent to 17.8 percent; the corresponding rate for women dropped from 24.7 percent to 16.8 percent. The UN flow rate for men declined from 17.9 percent to 15.8 percent and the rate for women, from 27.2 percent to 23.0 percent. On average, however, men were more likely to leave unemployment for employment, while women were more likely to leave unemployment and exit the labor force.

Since the UE and UN components of the outflow rates from unemployment declined in a comparable way for men and women during the 2007 recession, the declines in the aggregate outflow rates for men and women were also comparable. However, the $\mathrm{NU}$ and EU inflows to unemployment increased disproportionately for men, leading to a significantly greater increase in the aggregate inflow rate for men than for women.

\section{Accounting for the High Male Inflow Rate}

We have established that in the 2007 recession, men experienced a much greater increase in their flow rate from employment to unemployment than did women. In fact, the male EU flow rate at the peak of the gender gap was almost 70 percent higher than the female rate. This disparity can be traced in large part to the sectoral composition of job losses-specifically, the fact that job losses have been highly concentrated in the goods-producing industries of manufacturing and construction, which generally employ a higher proportion of male workers (Table 2). Moreover, within these industries, men have been hit harder by job losses than women. Men's employment declined 17.4 percent from its December 2007 level while women's dropped 15.3 percent. Although these percentage changes seem roughly comparable, they translate into very different measures of lost jobs because of the disproportionate representation of men in the goods-producing 
Chart 7

\section{Decomposition of Inflow and Outflow Rates by Gender}
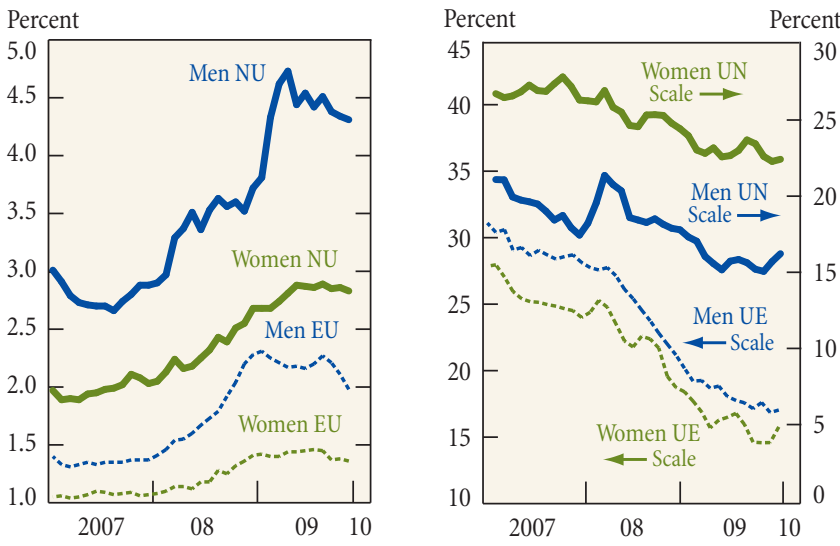

Sources: U.S. Department of Labor, Bureau of Labor Statistics; authors' calculations.

industries. Indeed, men lost 2.9 million jobs while women lost only one quarter of that number, or 765,000 jobs.

Significantly, the industries that have fared better during the current recession are health care and education, which have a heavier representation of women than men. Women's employment in these industries has risen 3.7 percent, for a gain of 533,000 jobs, while men's employment increased 3.1 percent, netting only 129,000 jobs.

The sectoral composition of job losses accounts for a significant part of the gender differences in the flows from employment to unemployment. ${ }^{9}$ But why did the flow rates from nonparticipation to unemployment increase so much more for men than for women? We know that when labor market conditions are weak, it is typical for many unemployed workers to drop out of the labor force while they wait for job prospects to improve. However, during the most recent recession, it appears that a large number of men who withdrew became less willing to sit out the weak labor market and instead renewed their search for work. In addition, it is likely that the depressed economy prompted longterm nonparticipants in the labor market (for example, retirees and students) to begin a job search. We speculate that men in both of these groups - those who retreated from a job search for a brief period and those who were long-term nonparticipantsreturned to the job market in the 2007 recession because they had run down their savings or experienced a decline in their total wealth (through, say, a drop in home equity and retirement savings) during their absence from the labor force. ${ }^{10}$

While the substantial increase in male flow rates from nonparticipation to unemployment during the 2007 recession was without precedent in the 1990-91 and 2001 recessions, the smaller increase observed for women was consistent with the increases in the two previous recessions. This conformity with the historical

\footnotetext{
${ }^{9}$ Wall (2009) offers a different perspective on this gender gap when he suggests that younger and less educated men had poorer labor outcomes than their women counterparts during the most recent recession. For in-depth analysis of labor outcomes of various demographic groups, see Elsby, Hobijn, and Şahin (2010).

${ }^{10}$ Compare the argument put forward by Daly, Hobijn, and Kwok (2009) on the effects of wealth on labor supply; the authors contend that reduced wealth and liquidity prompt people not in the labor force to initiate a job search.
}

\section{Sectoral Composition of Job Losses, December 2007-August 2009}

Percent

\begin{tabular}{|c|c|c|c|c|}
\hline Sector & $\begin{array}{l}\text { Change in Payroll Employment } \\
\text { since Start of Recession }{ }^{\mathrm{a}}\end{array}$ & $\begin{array}{l}\text { Change in } \\
\text { Women's Employment }^{\mathrm{a}}\end{array}$ & $\begin{array}{c}\text { Change in } \\
\text { Men's Employment }^{\mathrm{a}}\end{array}$ & $\begin{array}{l}\text { Share of Male Workers } \\
\text { at Start of Recession }\end{array}$ \\
\hline Goods & -16.9 & -15.31 & -17.37 & 77.3 \\
\hline Manufacturing & -14.9 & -15.59 & -14.61 & 71.2 \\
\hline Construction & -21.4 & -15.80 & -22.25 & 87.5 \\
\hline Natural resources and mining & -8.3 & 1.03 & -9.66 & 86.8 \\
\hline Services & -3.6 & -2.49 & -4.85 & 46.3 \\
\hline Trade and transportation & -7.1 & -7.04 & -7.10 & 59.1 \\
\hline Information & -8.2 & -9.82 & -6.95 & 57.6 \\
\hline Financial activities & -6.5 & -6.53 & -6.37 & 40.7 \\
\hline Professional and business services & -9.3 & -8.33 & -10.09 & 55.3 \\
\hline Education and health services & 3.6 & 3.72 & 3.06 & 22.7 \\
\hline Leisure and hospitality & -3.3 & -3.59 & -3.07 & 47.5 \\
\hline Other services & -2.9 & -1.88 & -4.05 & 47.9 \\
\hline Government & 0.6 & 0.87 & 0.32 & 43.0 \\
\hline
\end{tabular}

Sources: U.S. Department of Labor, Bureau of Labor Statistics; authors' calculations.

aData through August 2009.

${ }^{b}$ Data from December 2007. 
pattern explains the relatively flat female labor force participation rate during the 2007 recession. To the extent that the $\mathrm{NU}$ flow rate for women increased in the most recent recession, we hypothesize that the rise was due to the "added worker effect." In this phenomenon, the loss of a job by one member of a household increases another member's willingness to supply labor. Juhn and Potter (2007), for example, find that married women whose spouses lose their jobs or leave the labor force are more likely to enter the labor force than women whose spouses remain employed. In our view, the severity of the most recent recession and its disproportionate negative effect on males make it all the more likely that the added worker effect is at play in the increased NU flows for women.

\section{Conclusion}

Our look at the labor market outcomes for men and women during the most recent recession reveals a far more substantial adverse effect on men than on women. Analyzing labor market flows separately for men and women, we conclude that the high unemployment gender gap stems principally from the higher unemployment inflow rate for men. This higher rate in turn reflects the deterioration of male-dominated industries during the 2007 recession and the increase in the percentage of men whoprompted, very likely, by a decline in household liquidity - have entered (or reentered) the labor force but failed to find work. Surprisingly, the likelihood of moving out of unemployment is remarkably similar for men and women.

Recent analysis of the flows data suggests that the inflow rate to unemployment has begun to come down for both men and women. Since the peak of the gender gap in August 2009, the inflow rate for men has declined from 2.9 percent to 2.7 percent while that for women has declined from 2.1 percent to 2.0 percent. In addition, the January 2010 data show a pickup in both groups' unemployment outflow rates for the first time since mid-2007. These improvements in the unemployment inflow and outflow rates suggest that a recovery in the labor market may be under way.

Still, with the U.S. economy going through major changes, a quick recovery in the labor market seems unlikely. The manufacturing sector has continued to shrink, while jobs in the construction sector are being redeployed. Thus, we expect that the labor market will also see significant structural changes_-permanent shifts in the distribution of workers throughout the economyjust as it did after the 2001 recession (Groshen and Potter 2003). As a result, a portion of the employment declines in the goods-producing sector during the 2007 recession will not be reversed, and reallocating the excess labor supply to other sectors will take time.

Many workers displaced from the goods-producing sector will eventually find employment elsewhere. However, as the labor literature attests, displaced workers often suffer substantial wage losses after reemployment since the skills that they developed for their previous jobs may not be applicable in their new positions (Jacobsen, LaLonde, and Sullivan 1993). Because most of these displaced workers are men who are likely to be primary earners in their household, their wage losses will put downward pressure on household income and consumption in the short to medium term. Given this negative chain of consequences, the implementation of training and job-search consulting programs to improve reemployment and earnings prospects may prove especially useful.

\section{References}

Daly, Mary, Bart Hobijn, and Joyce Kwok. 2009. “Labor Supply Responses to Changes in Wealth and Credit." Federal Reserve Bank of San Francisco Economic Letter, no. 2009-05, January 30.

Elsby, Michael, Bart Hobijn, and Ayşegül Şahin. 2009. “Unemployment Dynamics in the OECD." NBER Working Paper no. 14617, December.

- 2010. “The Labor Market in the Great Recession.” Unpublished paper.

Groshen, Erica, and Simon Potter. 2003. "Has Structural Change Contributed to a Jobless Recovery?" Federal Reserve Bank of New York Current Issues in Economics and Finance 9, no. 8 (August).

Hall, Robert E. 2006. "Job Loss, Job Finding, and Unemployment in the U.S. Economy over the Past Fifty Years." In Mark Gertler and Kenneth Rogoff, eds., NBER Macroeconomics Annual 2005: 101-66.

Jacobsen, Louis S., Robert J. LaLonde, and Daniel G. Sullivan. 1993."Earnings Losses of Displaced Workers." American Economic Review 83, no. 4 (September): 685-709.

Juhn, Chinhui, and Simon Potter. 2007. "Is There Still an Added Worker Effect?" Federal Reserve Bank of New York Staff Reports, no. 310, December.

Shimer, Robert. 2005. "The Cyclical Behavior of Equilibrium Unemployment and Vacancies." American Economic Review 95, no. 1 (March): 25-49.

Wall, Howard J. 2009. “The 'Man-Cession' of 2008-09: It’s Big, but It’s Not Great.” Federal Reserve Bank of St.Louis Regional Economist 17, no. 4 (October): 5-9.

\section{ABOUT THE AUTHORS}

Ayşegül Şahin is a senior economist in the Macroeconomic and Monetary Studies Function and Joseph Song an assistant economist in the Microeconomic and Regional Studies Function of the Federal Reserve Bank of New York; Bart Hobijn is a research advisor in the Microeconomics Group of the Federal Reserve Bank of San Francisco.

Current Issues in Economics and Finance is published by the Research and Statistics Group of the Federal Reserve Bank of New York. Linda Goldberg and Charles Steindel are the editors.

The views expressed in this article are those of the authors and do not necessarily reflect the position of the Federal Reserve Bank of New York or the Federal Reserve System. 